\title{
MEKANISME ERUPSI DAN MODEL KANTONG MAGMA GUNUNGAPI IJEN
}

\author{
Oleh: \\ Hena Dian Ayu ${ }^{1}$, Akhmad Jufriadi ${ }^{2}$
}

\begin{abstract}
ABSTRAK : Mekanisme erupsi suatu gunungapi dapat dilihat berdasarkan karakteristik dan bagaimana model kantong magma gunungapi tersebut. Karakteristik dan posisi kantong magma dapat diestimasi dengan mengunakan metode seismik yaitu dengan menganalisa rekaman sinyal seismik dari suatu gempa vulkanik maupun tektonik. Analisis terhadap rekaman sinyal gempa vulkanik (tipe A dan tipe B) dan tremor harmonik yang didapatkan dari 3 stasiun seismik yaitu Ijen (Ijen), Terowongan Ijen (TRWI) dan Kawah Utara Ijen (KWUI) dilakukan dengan cara menyeleksi sinyal berdasarkan waveform dan dilihat pola spektralnya untuk mendapatkan kandungan frekuensinya. Analisis hiposenter dilakukan untuk mengetahui kedalaman gempa vulkanik dan mengestmasi dimanakah dan bagaimana model kantong magmanya. Dari perhitungan diperoleh sebaran posisi hiposenter berada pada kedalaman berkisar 0-2.500 meter dibawah Kawah Ijen untuk Gempa VB, 2.000-2.500 meter dibawah Kawah Ijen untuk Gempa VA dan 5.000-50.000 meter dibawah permukaan laut untuk Gempa Tektonik Lokal. Hasil penelitian menunjukkan daerah aseismik berada pada kedalaman lebih dari 4000 meter dibawah permukaan laut, yang diindikasikan sebagai kantung magma. Adapun proses internal yang terjadi adalah lebih disebabkan oleh adanya pergeseran patahan karena terjadi peningkatan aktivitas magma. Dan didapatkan pula bahwa model kantong magmanya bersistem ganda. Pada model ini, Letusan dapat dipandang sebagai terjadinya proses pengosongan kantong magma dangkal. Gaya eksternal $F(t)$ dianalogikan tekanan magma yang mengandung gas $P m(t)$, gaya pegas $(-k y)$ analog dengan tekanan hidrotermal dari air danau kawah. Diasumsikan bahwa ketika gaya eksternal yang mendorong massa sudah melebihi gaya pegas dan redamannya yang menahan massa, maka gaya eksternal akan keluar pada panjang pegas dan massa akan memantul kembali. Keadaan tersebut dianalogikan dengan terjadinya erupsi, yaitu ketika tekanan magma $(P m)$ sudah melebih tekanan hidrotermal $(P h)$, maka tekanan akan keluar dan terjadi erupsi.
\end{abstract}

Kata kunci: gempa vulkanik, Gunung Ijen, hiposenter

\begin{abstract}
A volcanic eruption mechanism can be viewed based on characteristics and volcanic magma chamber model. Characteristics and position of the magma chamber can be estimated using the seismic method by analyzing recorded seismic signals of a volcanic or tectonic earthquakes. Analysis of the recorded signals of volcanic earthquakes (type A and type B) and harmonic tremors obtained from three seismic stations are Ijen (Ijen), Tunnel Ijen (TRWI) and the Northern Crater Ijen (KWUI) was conducted by selecting visible signals based on waveform and spectral pattern to obtain its frequency. Hypocenter Analysis was conducted to determine the depth of volcanic earthquakes and to estimate position and the magma bag model. From the calculations, the distribution of the hypocenter position was at a depth $0-2500$ meters below The Mt. Ijen creater. The Earthquake VB type, 2,000-2,500 meters below The Mt. Ijen crater, the Earthquake VA type 5000-50000 meters below sea level for Local Tectonic earthquake. It showed seismic area is at a depth of more than 4000 meters below sea level indicating magma pockets. The internal processes occurred were caused by the shift of the fault due to increasing of magma activities. It was also found that the magmanya bag model is the dual-system. In this model, the eruption can be seen as the process of emptying the shallow magma chamber. External force $F(t)$ is analogous to the pressure of magma containing Pm (t) gas, the spring force (-ky) is analogous to the hydrothermal pressure of crater lake water. It was assumed that when the external force pushing the masses already exceeds the spring force and the damping force holding the massess then the external force is presented on the length of the spring and the mass is bounced back. The situation is analogous to the eruption, when magma pressure ( $\mathrm{Pm})$ already exceeds the hydrothermal pressure $(\mathrm{Ph})$, then the pressure will come out and eruption is happened.
\end{abstract}

Keyword : vulcanic earthquake, Mt. Ijen, Hypocenter

${ }^{1,2)}$ FKIP-Jurusan Pendidikan Fisika, Universitas Kanjuruhan Malang

(hena_dian@yahoo.com) 


\section{PENDAHULUAN}

Gunungapi Ijen Jawa Timur merupakan salah satu gunung dari delapan buah gunungapi yang memiliki danau kawah dengan air danau yang bersifat asam. Letak geografis puncaknya $8^{\circ} 03^{\prime} 30^{\prime}$ ' Lintang Selatan dan $114^{\circ} 14^{\prime} 30^{\prime}$ ' Bujur Timur, dengan ketinggian tepi kawah sebesar $2386 \mathrm{~m}$ dpl dan danau kawah $2145 \mathrm{~m}$ dpl. Gunung dengan tipe strato ini secara administratif masuk dalam wilayah Kabupaten Banyuwangi dan Bondowoso Propinsi Jawa Timur [7], Sebagaimana tampak pada Gambar 1. Pemantauan terhadap aktivitas Gunung Ijen secara berkala dan terus menerus dilakukan saat ini terkait dengan meningkatnya beberapa status gununapi di Indonesia. Gunungapi Ijen sendiri pada saat penelitian ini dilakukan berada pada status siaga. Pengamatan terhadap aktivitas Gunungapi yang bertujuan untuk mengurangi dampak negatif terhadap keberadaan gunungapi terutama terkait dengan mitigasi bencana, pada umumnya dilakukan dengan menggunakan metode seismik, deformasi, geofisika, visual dan geokimia. Dari metodemetode tersebut, metode seismik merupakan metode yang paling banyak digunakan. Hal ini disebabkan adanya peningkatan aktivitas kegempaan di bawah gunungapi sebelum terjadinya erupsi, karena magma dan gas gunungapi harus terlebih dahulu mendorong ke permukaan melalui rekahan dan lorong-lorong. Ketika magma dan gas vulkanik berpindah akan menyebabkan retakan hingga pecahnya batuan. Retakan atau pecahnya batuan ini akan menjadi sumber getaran berupa sinyal gelombang seismik. Sebagaimana penelitian Hendrasto, yang telah berhasil mengidentivikasi karakteristik Gunungapi Ijen berdasarkan aktivitas kegempaannya atau dari hasil analisis sinyal seismik yaitu bahwa Gunungapi Ijen secara umum didominasi oleh kemunculan gempa vulkanik tipe B (VB), tektonik jauh, dan gempa hembusan [3]. Secara lebih lanjut dengan menganalisis sinyal seimik akan didapatkan keterkaitan antara sinyak seismik yang satu dengan yang lain sehingga dapat diteliti seperti apa proses internal yang terjadi pada Gunungapi Ijen dengan begitu dapat diestimasi bagaimana dan dimana posisi kantong magma Gunungapi Ijen sehingga dapat diperkirakan bagaimana mekanisme erupsinya terkait dengan tipe letusannya yaitu bertipe freatik. Hasil penelitian ini nantinya juga akan dapat digunakan sebagai rujukan untuk memahami proses internal yang terjadi pada gunungapi lain dengan karakteristik letusan yang sama.

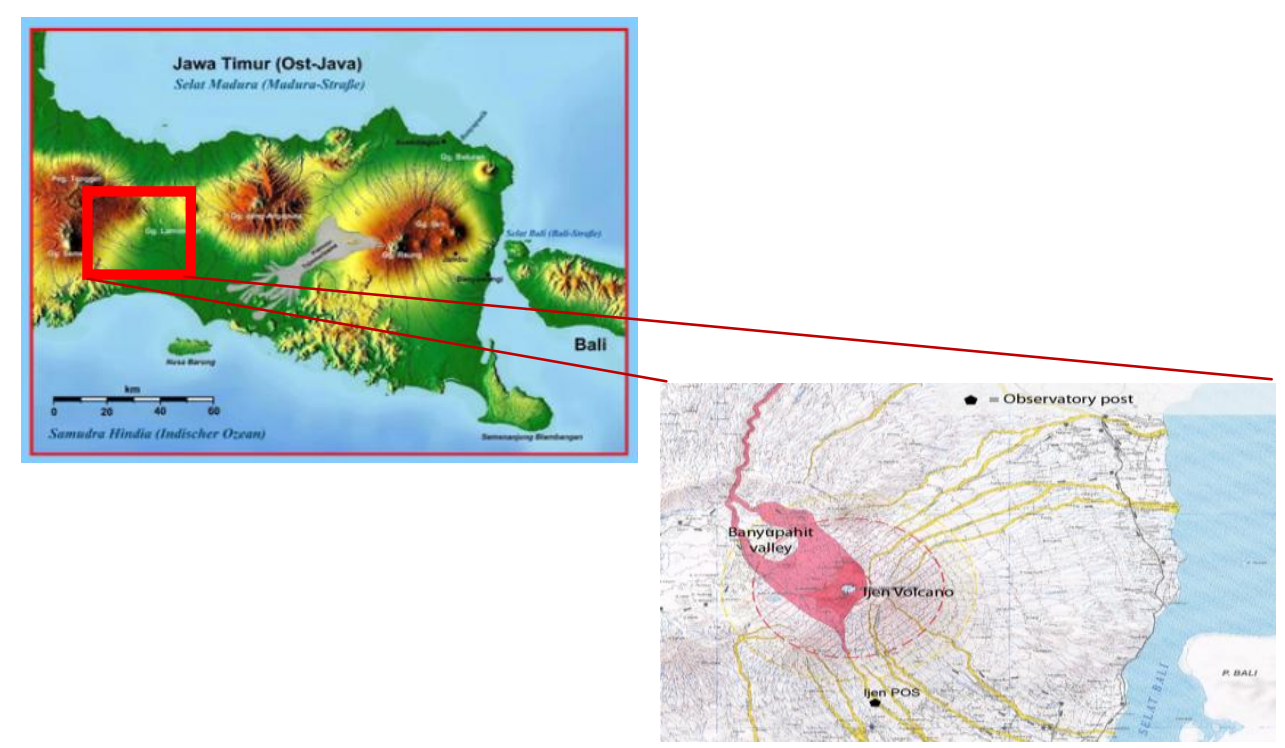

Gambar 1. Peta Lokasi Gunungapi Ijen 
Penelitian diawali dengan menganalisis data seismik digital hasil rekaman (seismogram) yang didapatkan dari Pos Pengamatan Gunungapi (PPGA) Ijen, Banyuwangi. Pengukuran data primer dilakukan oleh stasiun pencatat yang terdapat di beberapa titik sekitar Gunung Ijen, yaitu: Stasiun Ijen, Stasiun Terowongan Ijen dan Stasiun Kawah Utara Ijen yang di monitoring oleh PPGA Ijen. Penelitian ini fokus pada pengolahan data sekunder dan analisis lebih lanjut terhadap output dari pengolahan data. Penelitian ini dilakukan dalam beberapa tahap yaitu :

1. Seleksi rekaman data seismik merupakan langkah awal dalam pengolahan data yang bertujuan untuk mengetahui jenis gempa yang ada di Gunungapi Ijen, dan untuk memilah data rekaman seismik yang dapat ditelaah lebih jauh kandungan informasi di dalamnya. Hal ini dikarenakan, tiap sinyal seismik membawa Informasi seputar model terjadinya gempa, intensitasnya, dan besaran fisis lain yang sangat diperlukan untuk banyak penelitian ilmiah. Berikut contoh data seismogram gempa vulkanik Gunungapi Ijen.

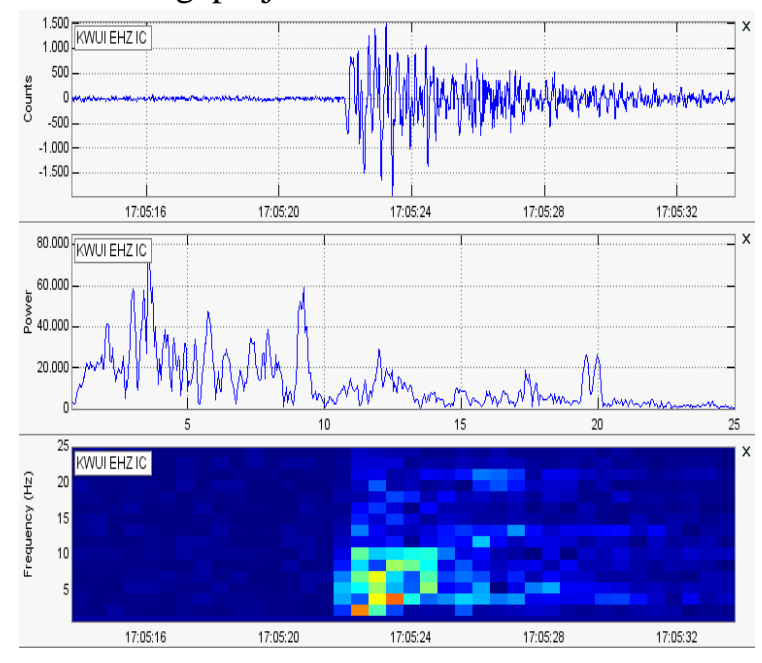

Gambar 2. Seismogram gempa vulkanik

Data dapat terbilang baik jika memenuhi beberapa syarat, diantaranya :

a. Posisi waktu tiba gelombang $\mathrm{P}$ dan gelombang $\mathrm{S}$ yang jelas,

b. Terekam minimal di 3 stasiun untuk penentuan hiposenter gempa,

c. Penampakan event jelas dan menggambarkan pola jenis gempa tertentu.

2. Analisis nilai frekuensi, amplitudo dan waktu tiba terjadinya gempa.

3. Penentuan posisi sumber dari masing-masing gempa vulkanik dengan menggunakan hasil analisis terhadap waktu tiba terjadinya gempa.

4. Identifikasi hubungan antara perkembangan posisi hiposenter dengan proses migrasi magma

5. Interpretasi proses internal gunung Ijen berdasar perubahan posisi hiposenter gempa vulkanik.

Dua hal yang sangat penting untuk dianalisa adalah karakteristik gempa dan perkembangan posisi hiposenter dari banyaknya kejadian Gempa Vulkanik, untuk memahami proses internal Gunungapi Ijen. Hal lain yang diperlukan adalah parameter fisis air danau kawah untuk memahami keterkaitannya dengan peningkatan aktivitas kegempaan. Pada analisis karakteristik ini, pertama yang dilakukan adalah menganalisis 
bahwa event terpilih dari semua stasiun diduga berasal dari sumber yang sama dengan membandingkan pola waveform, spektral ataupun spektrumnya.Penentuan posisi sumber gempa menyangkut pada 2 hal penting, yaitu posisi sumber di kedalaman, yang sering disebut sebagai hiposenter, dan posisi di permukaan, yang tegak lurus dengan posisi hiposenter, yang sering disebut sebagai episenter. Metode penentuannya adalah dengan menganalisa beda waktu tiba gelombang $\mathrm{P}$ dan $\mathrm{S}$ antar masing-masing stasiun. Adapun dasar penghitungannya adalah dengan persamaan berikut [5] :

$$
\begin{aligned}
& \left(X_{0}-X_{1}\right)^{2}+\left(Y_{0}-Y_{1}\right)^{2}+\left(Z_{0}-Z_{1}\right)^{2}=\left(t_{i}-t_{0}\right)^{2} V p^{2} \\
& \left(t_{i}-t_{0}\right) V p=(S-P)_{i} k
\end{aligned}
$$

dengan : $i=1,2,3$, dan 4 ( stasiun ke- $i),(X, Y, Z)_{0}=$ koordinat sumber gempa yang tidak diketahui,$(X, Y, Z) I=$ koordinat stasiun seismograph, $k=$ koefisien jarak yang tidak diketahui. $t_{i}=$ waktu tiba gelombang $\mathrm{P}, t_{0}=$ saat terjadinya gempa yang tidak diketahui .

Konstanta jarak $(k)$ merupakan konstanta Omori, yang digunakan dalam perhitungan hiposenter, dirumuskan sebagai berikut :

$$
k=\frac{V_{p} x V_{s}}{V_{p}-V_{s}}
$$

$V_{P}=$ Cepat rambat gelombang $\mathrm{P}$

$V_{S}=$ Cepat rambat gelombang $\mathrm{S}$

\section{HASIL DAN PEMBAHASAN}

\section{Hasil Pengamatan Aktivitas Gempa Vulkanik Gunungapi Ijen.}

Berdasarkan laporan pengamatan Gunungapi Ijen gempa vulkanik (tipe-A, tipe-B) dan tremor vulkanik Gunung Ijen mengalami fluktuasi dari jumlah kejadian. Hal tersebut menunjukkan bahwa gunungapi Ijen merupakan gunungapi yang aktif. Aktivitas kegempaan Gunung Ijen mengalami peningkatan tinggi ditandai oleh peningkatan gempa vulkanik dalam (VA) dan gempa vulkanik dangkal (VB) diikuti oleh terjadinya Tremor Harmonik terjadi peningkatan yang cukup tajam pada kejadian gempa vulkanik yaitu 49 Gempa Vulkanik Dalam (VA) dan 102 Gempa Vulkanik Dangkal (VB). Dari data perhitungan energi gempa vulkanik, peningkatan jumlah gempa vulkanik diikuti oleh peningkatan energi gempa vulkanik yang mencapai $4,21 \times 10^{14}$ dan $2,1 \times 10^{15} \mathrm{erg} / \mathrm{hari}$.

Peningkatan aktivitas kegempaan Gunungapi Ijen yang ditandai dengan terjadinya peningkatan gempa vulkanik diikuti oleh Tremor Harmonik telah meningkatkan status Gunung Ijen dari kondisi Normal (Level I) menjadi Waspada (Level II). Kemudian meningkatnya energi vulkanik yang tinggi menjadikan Gunung Ijen dinaikkan statusnya menjadi Siaga (Level III). Status kegiatan Gunung Ijen diturunkan dari Siaga menjadi Waspada, karena terjadi penurunan aktivitas kegempaan baik gempa vulkanik dalam ataupun gempa vulkanik dangkal. 


\section{Proses Internal Gunung Ijen Terkait Dengan Seismisitasnya}

Proses di dalam Gunung Ijen terkait dengan seismisitasnya merupakan proses migrasi magma yang disebabkan oleh adanya peningkatan aktivitas magma. Magma dan gas gunung api terus mendorong ke permukaan melalui rekahan-rekahan dan loronglorong. Ketika magma dan gas vulkanik berpindah akan menyebabkan retakan hingga pecahnya batuan. Retakan atau pecahnya batuan ini akan menjadi sumber getaran. Ketika batu pecah dengan frekuensi tinggi, akan menimbulkan gempa vulkanik. Jika retakan bergetar dengan frekuensi rendah secara terus menerus akan menyebabkan terjadinya tremor vulkanik. Sehingga aktivitas magma tersebut menyebabkan terjadinya peningkatan jumlah aktivitas gempa vulkanik (tipe-A dan tipe-B) dan tremor vulkanik. Dari gambar grafik kegempaan terdapat adanya peningkatan gempa vulkanik, diduga dipicu oleh meningkatnya gempa tektonik lokal yang terjadi karena adanya kegiatan tektonik. Seperti dijelaskan sebelumnya bahwa peningkatan gempa vulkanik, baik vulkanik dalam maupun vulkanik dangkal tersebut diikuti oleh tremor harmonik yang menunjukkan aktivitas magma terus bergerak menuju permukaan. Hal ini juga didukung dengan kecenderungan peningkatan suhu pada kedalaman 5 meter. Perubahan suhu tersebut menunjukkan bahwa terjadi interaksi secara langsung ataupun tidak antara air kawah dengan magma atau gas vulkanik. Di Kawah Ijen, adanya interaksi secara langsung ataupun tidak antara air kawah dan magma menyebabkan adanya stratifikasi termal, yang menyebabkan air pada kedalaman kawah memiliki temperatur tinggi sedangkan pada permukaan air kawah temperatur rendah terutama pada musim hujan. Tidak bercampurnya lapisan air atas dengan bagian bawah pada kedalaman tertentu menyebabkan perbedaan karakteristik fisis dan kimiawi. Bersatunya lapisan air yang memiliki sifat termal, sifat fisis serta sifat kimia berbeda dapat menyebabkan terjadinya bualan atau upwelling yang merupakan fenomena erupsi [2]. Upwelling terdapat pada Gambar 3.

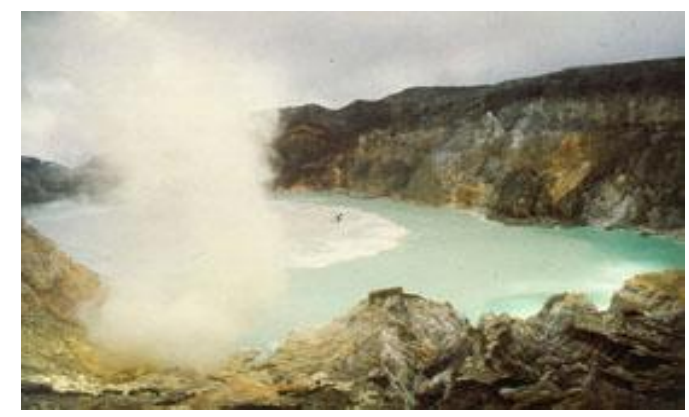

Gambar 3. Letusan Kawah Ijen berupa "upwelling"

Dugaan adanya migrasi magma yang menuju permukaan tersebut juga didukung dengan perubahan visual air danau kawah. Dari pengamatan visual terlihat adanya perubahan warna air danau kawah, jika dibandingkan dengan pengamatan pada saat kondisi normal (Waspada). Pada status Siaga tampak warna air danau kawah putih berbuih dan berbunyi kemericik, uap air danau kawah putih tipis merata diseluruh permukaan danau. Selain itu juga tampak adanya bualan air ditengah kawah dengan diameter kurang lebih 5 meter. Bualan dengan tekanan rendah tersebut merupakan model letusan freatik. Perubahan visual tersebut disebabkan oleh adanya suplai gas magmatik dalam dan migrasi magma yang sudah mendekati permukaan atau dibawah kawah Ijen. Sehingga terjadi 
interaksi langsung ataupun tidak antara magma atau gas magmatik dengan air danau kawah.

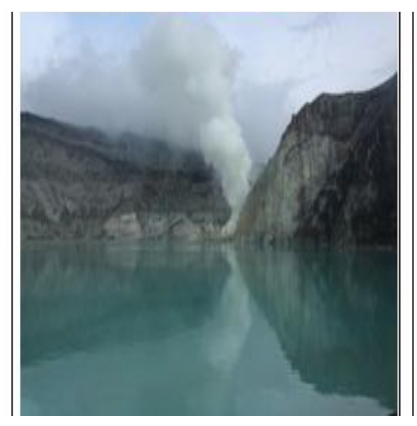

a.Waspada

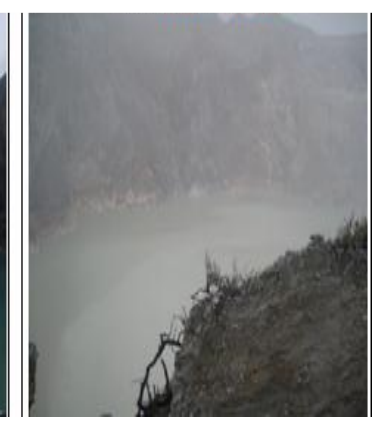

b. Siaga

Gambar 4. Perbandingan visual danau kawah

\section{Posisi Hiposenter Dan Keterkaitannya Dengan Proses Internal Gunung Ijen.}

Hasil analisis posisi sumber gempa memperlihatkan adanya migrasi magma menuju permukan. Untuk memudahkan pembacaan hasil posisi sumber gempa dalam bentuk koordinat disajikan dalam irisan 2 dimensi penampang samping yang mencerminkan hiposenter dalam arah Barat-Timur dan Selatan-Utara, yang disajikan pada Gambar 5. Pada irisan 2 dimensi, posisi sumber gempa ditunjukkan dengan simbol bulat (bulat merah menunjukkan Gempa Vulkanik A, bulat biru menunjukkan Gempa Vulkanik B dan bulat magenta menunjukkan tektonik lokal) sedangkaan posisi stasiun pencatat yang ada di Gunungapi Ijen ditunjukkan dengan simbol segitiga biru. Dari sebararan posisi hiposenter penampang Selatan-Utara pada Gambar 5 dapat di interpretasikan bahwa pada kedalaman sekitar sekitar 0 - 500 meter di bawah permukaan laut terdapat horizontal crack. Hal ini dapat dilihat dari posisi hiposenter pada kedalaman tersebut berada pada satu garis horizontal. Pada penampang tersebut juga tampak daerah aseismik pada kedalaman sekitar 2.000 meter dan 4.000 meter. Dan terlihat juga daerah aseismik pada kedalaman sekitar 2.000 meter dan pada kedalaman 4.000 meter. Daerah aseismik yang terlihat pada penampang Selatan-Utara dan Barat-Timur, di interpretasikan bahwa pada kedalaman tersebut merupakan daerah kantong magma. Sehingga gunung Ijen bisa dikategorikan sebagai gunungapi dengan sistem dua kantong magma, yaitu kantong magma dangkal (kedalaman 2.000 meter dan dinding kawah bawah kedalaman 2.500 meter) dan kantong magma dalam (kedalaman 4.000 meter).

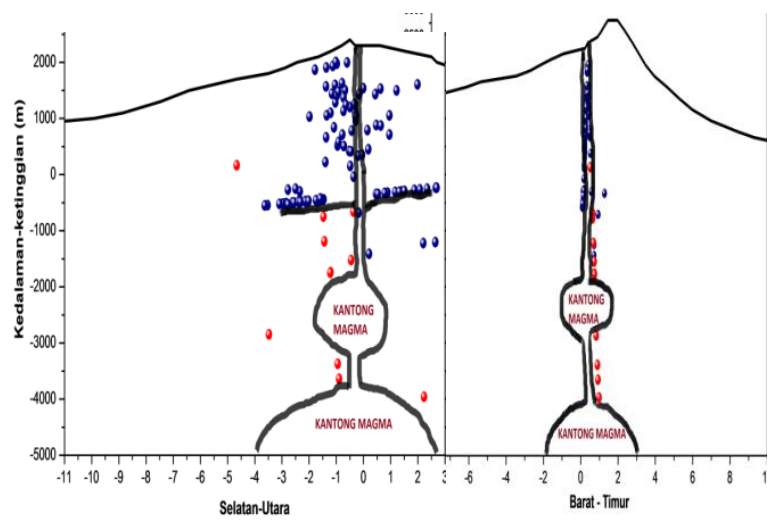

Gambar 5. Model Kantong Magma berdasarkan hiposenter gempa vulkanik 
Dari Gambar 5 tampak bahwa posisi sumber gempa vulkanik tipe-B (VB) berada pada kedalaman berkisar 0 - 2.500 meter di bawah Kawah Ijen. Untuk gempa vulkanik tipe-A (VA) berada pada kisaran kedalaman 2.000 - 6.500 meter di bawah Kawah Ijen. Gempa vulkanik tipe-A tersebut dapat dibagi menjadi gempa vulkanik tipe-A dangkal (VAs) dengan kedalaman 2.000 - 2.500 meter dan gempa vulkanik tipe-A dalam $\left(\mathrm{VA}_{\mathrm{d}}\right)$ pada kedalaman 2.500 - 6.500 meter. Sedangkan gempa tektonik lokal berada pada kedalaman 10.000 - 50.000 meter dibawah permukaan laut. Secara konseptual proses internal Gunungapi Ijen dapat dijelaskan seperti diagram pada Gambar 6.

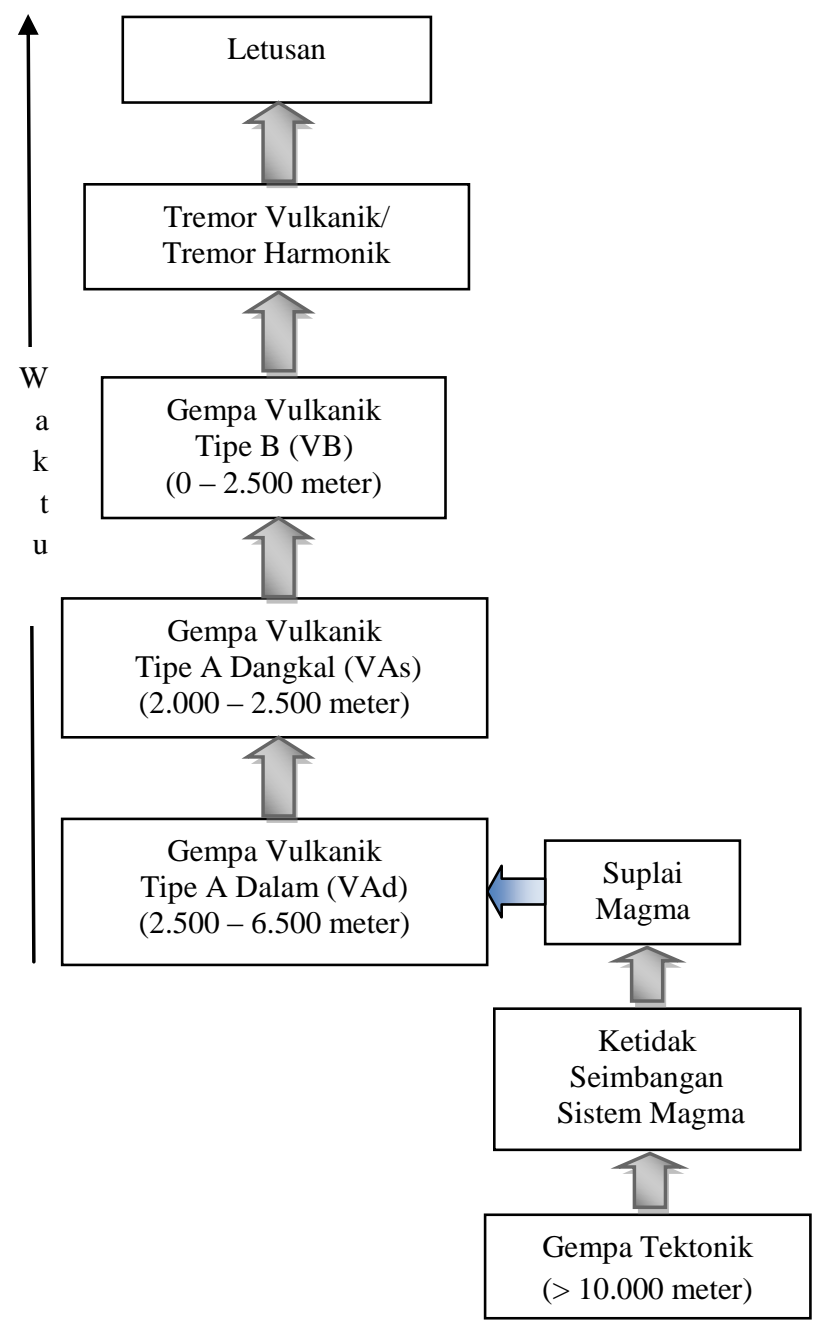

Gambar 6. Urutan Waktu Kejadian Gempa Vulkanik

\section{Mekanisme Erupsi Terkait dengan Model Kantung Magma Ganda}

Pada model gunungapi dengan sistem kantong magma ganda, Letusan dapat dipandang sebagai terjadinya proses pengosongan kantong magma dangkal. Beberapa saat kemudian kantong magma yang kosong tersebut terisi fluida yang disuplai dari kantong magma dalam. Pengisian kantong magma dangkal oleh kantong magma dalam terus berlangsung sampai tercapai tekanan maksimum selanjutnya. Ketika tekanan magma sudah maksimum dan melebihi tekanan hidrotermal yang terjadi karena adanya pemanasan air danau kawah, maka tekanan akan keluar dan terjadi erupsi. 
Proses migrasi magma yang terjadi dalam Gunung Ijen dipicu oleh adanya kegiatan tektonik disekitar gunung yang menghasilkan gempa tektonik lokal. Meningkatnya kejadian gempa tektonik menyebabkan terganggunya sistem keseimbangan magma. Ketidak seimbangan tersebut menghasilkan pergerakan magma atau gas dalam piromagma ke arah permukaan bumi melalui celah atau lorong-lorong diatasnya karena tekanan dalam piromagma lebih besar dari tekanan beban luar. Pergerakan magma dan gas ke arah permukaan yang terjadi, terus menerobos celah sehingga timbul retakan yang mennyebabkan terjadinya gempa vulkanik dalam (VA). Pergerakan magma yang mendekati permukaan melalui lorong atau celah diatasnya menyebabkan terjadinya fluktuasi tekanan sehingga terjadi gempa vulkanik dangkal (VB). Migrasi magma pada permukaan dangkal menyebabkan terbukanya rekahan batuan atau retakan bahkan pecahnya batuan. Retakan atau pun pecahnya batuan dengan frekuensi rendah secara terus menerus menimbulkan terjadinya tremor vulkanik. Mekanisme sumber terjadinya gempa vulkanik dalam (VA) dan dangkal (VB) adalah adanya retakan batuan dan fluktuasi tekanan [6]. Magma yang sampai pada permukaan atau mendekati permukaan (titik bagian paling dalam kawah ijen) akan bersentuhan langsung ataupun tidak dengan air kawah. Proses internal yang berhubungan dengan terjadinya migrasi magma juga pernah diteliti pada Gunungapi Semeru. Gunung ini memiliki karakter yang berbeda dengan Gunungapi Ijen. Dari sifat materialnya Gunungapi Semeru merupakan tipe gunung andesitik dengan letusan bersifat vulkanian dan strombolian, sedang untuk Gunung Ijen merupakan tipe andesitik - basaltik dan letusannya bersifat freatik. Hal tersebut sangat berbeda dengan perilaku erupsi gunung Ijen yang mempunyai tipe freatik. Mengacu pada distribusi posisi sumber gempa dan geologi strukturnya. Pada Gunung semeru yang memiliki posisi episenter jauh dari pusat kawah (lebih dari $8 \mathrm{~km}$ keatas) mengindikasikan bahwa gempa tidak hanya bersumber dari sekitar pusat conduit saja, melainkan lebih meluas kedaerah sisi tubuh gunung [1]. Hal ini berbeda dengan Gunung Ijen yang memiliki posisi episenter gempa vulkanik berada disekitar kawah yang menunjukkan bahwa gempa bersumber dari pusat conduit. Perilaku erupsi Gunung Ijen dengan letusan freatiknya dapat dimodelkan sebagai analogi suatu sistem massa pegas yang teredam. Hal ini selaras dengan model yang erupsi Gunungapi Semeru dengan aktivitas stromboliannya dapat dimodelkan sebagai analogi suatu sistem massa pegas yang teredam [4]. Perbedaan model ini terletak pada analogi yang digunakan. Pada Gunungapi Ijen gaya eksternal $F(t)$ dianalogikan tekanan magma yang mengandung gas $P m(t)$, gaya pegas (-ky) analog dengan tekanan hidrotermal dari air danau kawah. Pada model ini diasumsikan bahwa ketika gaya eksternal yang mendorong massa sudah melebihi gaya pegas dan redamannya yang menahan massa, maka gaya eksternal akan keluar pada panjang pegas dan massa akan memantul kembali. Keadaan tersebut dianalogikan dengan terjadinya erupsi, yaitu ketika tekanan magma $(P m)$ sudah melebih tekanan hidrotermal $(P h)$, maka tekanan akan keluar dan terjadi erupsi. Analogi tersebut bisa digambarkan secara sederhana seperti Gambar 7. 


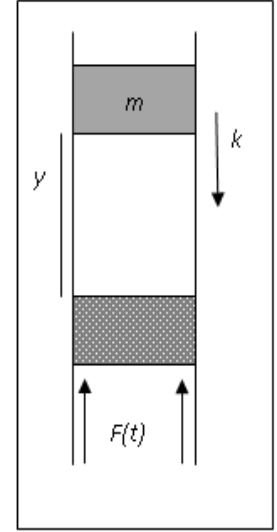

(a)

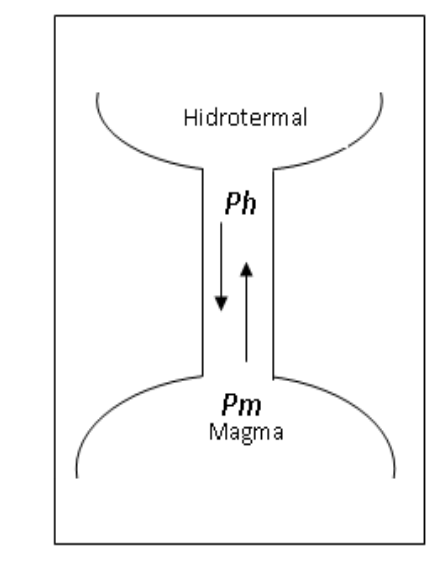

(b)

Gambar 7. (a) Model Sistem Massa Pegas Teredam dan (b) Analogi Perilaku Erupsi Gunungapi Ijen

\section{KESIMPULAN}

Berdasarkan analisis pada rekaman sinyal seismik dari berbagai tipe gempa pada penelitian ini maka dapat ditarik beberapa kesimpulan yaitu :

1. Aktivitas Gempa Vulkanik Gunung Ijen mengalami peningkatan tinggi ditandai dengan peningkatan gempa vulkanik dalam (VA) dan gempa vulkanik dangkal (VB) diikuti oleh tremor harmonik serta peningkatan energi gempa vulkanik. Peningkatan aktivitas kegempaan tersebut juga ditandai dengan perubahan fisis dari air danau kawah seperti perubahan warna, peningkatan temperatur.

2. Karakteristik gempa vulkanik dilihat dari waveform nya memiliki ciri sinyal dengan amplitude berkisar 5-46 mm, lama gempa berkisar 6-45 detik, kandungan frekuensi berkisar 3,4 Hz untuk Gempa Vulkanik Dalam (VA) dan untuk Gempa Vulkanik Dangkal (VB) sinyal memiliki ciri amplitude berkisar $3-46 \mathrm{~mm}$, lama gempa berkisar 5 - 25 detik, kandungan frekuensi berkisar $2,6 \mathrm{~Hz}$.

3. Sebaran posisi sumber gempa berada pada kedalaman berkisar $0-2.500$ meter dibawah Kawah Ijen untuk Gempa Vulkanik Dangkal (VB), 2.000 - 2.500 meter dibawah Kawah Ijen untuk Gempa Vulkanik Dalam (VA) dan 5.000 - 50.000 meter dibawah permukaan laut untuk Gempa Tektonik Lokal. Kemudian untuk episenter gempa vulkanik (VA dan VB) memusat disekitar kawah dengan jarak berkisar $2 \mathrm{~km}$ dan dominan pada arah tenggara dan timur laut. Sedangkan untuk gempa tektonik lokal berada disekitar gunung ijen dengan jarak berkisar $2-10 \mathrm{~km}$ dari kawah ijen pada arah tenggara dan timur laut.

4. Daerah aseismik berada pada kedalaman lebih dari 4.000 dan 2.000 meter dibawah permukaan laut, yang diinterpretasikan sebagai kantong magma. Sehingga gunung Ijen merupakan gunungapi dengan sistem kantong magma ganda.

5. Proses internal yang berhubungan dengan terjadinya migrasi magma disebabkan oleh adanya kegiatan tektonik disekitar gunung yang menyebabkan terganggunya sistem keseimbangan magma. Sehingga magma menerobos kepermukaan melalui celah atau 
retakan menyebabkan terjadinya gempa vulkanik dalam (VA), gempa vulkanik dangkal (VB) dan tremor vulkanik.

\section{DAFTAR PUSTAKA}

[1] Andryana, K., 2011. Mekanisme Fokus Gempa Vulkanik Tipe A Gunung Semeru. Jawa Timur - Indonesia, Tesis, Universitas Brawijaya, Malang.

[2] Chouet, B., 2003. Volcano Seismology, Pure and Applied Geophysics.160 (2003) 739788.

[3] Hendrasto, M., 2006. Pemantauan Seismisitas Gunung Ijen. Pusat Vulkanologi Dan Mitigasi Bencana Geologi. Bandung.

[4] Maryanto, S. 1999. Analysis of Seismic Signal of Mt Semeru (East Java, March 1st21st, 1988) In Order to Determine It's Source and Eruption Mechanism. Tesis. Universitas Gajahmada, Jogjakarta.

[5] Nishi, K.,2005, Hypocenter Calculation Software GAD (Geiger's method with Adaptive Damping). unpublished.

[6] Shearer, P.M., 2009. Introduction to Seismology. Second Edition. Cambridge University Press. Newyork.

[7] Sumarti, S., Bergen, M. V., Bogaard, T., Sukarnen dan Purwanto, H.B., 2006. Pemantauan Jangka Panjang Kawah Ijen (1922 - 2002) Parameter Fisis : Level Dan Temperatur. Pusat Vulkanologi Dan Mitigasi Bencana Geologi, Bandung.

[8] Surmayadi, M., Zaennudin, A. dan Abdurachman, E.K., 2006. Prakiraan Bahaya Gunungapi Ijen. Pusat Vulkanologi Dan Mitigasi Bencana Geologi, Bandung.

[9] Takano, B., Suzuki, K., Sugimori, K., Ohba, T., Fazlulin, S., Bernard, A., Sumarti, S., Sukhyar, R., Hirabayashi, M., 2004. Bathymetric and geochemical investigation of Kawah Ijen crater lake. East Java, Indonesia. Journal of Volcanology and Geothermal Research.

[10] Zobin, V.M., 2003. Introduction to Volcanic Seismology. Elsevier Science. Amsterdam. 